\section{Pengentasan \\ KeMISKINAN MELALUI SOCIALPRENEUR}

\author{
Yusriadi ', Saidna Zulfiqar bin Tahir2, \\ M. Awaluddin', Misnawati3 \\ 1)Administrasi Publik, Sekolah Tinggi \\ Ilmu \\ Administrasi \\ Puangrimaggalatung \\ 2) Pendidikan, Universitas I qra Buru \\ 3) Program Keluarga Harapan, \\ Kabupaten Bone
}

\author{
Article history \\ Received : 26-08-2020 \\ Revised : 16-10-2020 \\ Accepted : 07-11-2020
}

\section{*Corresponding author \\ Yusriadi \\ Email:}

yusriadi.yusriadi@uqconnect.edu.au

\begin{abstract}
Abstrak
Pada era pandemic Covid-19 ini, kehidupan ekonomi masyarakat semakin menurun, sehingga menimbulkan kesenjangan di masyarakat, terlebih lagi semakin menambah jumlah pengangguran akibat pemutusan hubungan kerja. Socialpreneur merupakan salah satu strategi atau kegiatan untuk memberdayakan masyarakat, dalam rangka mendukung upaya pengentasan kemiskinan pedesaan melalui pendekatan gender, yakni pemberdayaan perempuan melalui ibu-ibu penerima bantuan PKH dengan maksud terbentuknya semangat berwirausaha sebagai wujud memberdayakan ibuibu melalui pembuatan sabun cuci, jajanan tradisional, dan kegiatan konveksi. Pengabdian ini dilaksanakan di Kecamatan Cina Kabupaten Bone, dengan membina 8 ibu-ibu penerima bantuan PKH. Kegiatan ini dimulai dengan motivasi, pengenalan kewirausahaan, melihat kebutuhan pasar, desain produk, branding produk dan pemasaran produk berbasis teknologi informasi. Luaran dari kegiatan ini berupa terbentuknya socialpreneur di kalangan ibu-ibu yang mampu memberikan penghasilan tambahan kepada keluarga, dan terciptanya produk barang kebutuhan rumah tangga yang layak dipasarkan secara luring dan daring.
\end{abstract}

Keywords: Pengentasan Kemiskinan; Pemberdayaan; Gender; PKH; Indonesia

\begin{abstract}
During the Covid-19 pandemic, the community's economic life declined and caused gaps in society, significantly increasing unemployment caused by layoffs. Entrepreneurship is one strategy or activity to empower the community to reduce rural poverty by a gender approach. It was namely empowering women by using the PKH mothers, to build an entrepreneurial spirit as a way of allowing by making washing soap, traditional snacks, and convection business. This service was carried out by fostering eight mothers in China, Bone Regency, who received PKH assistance. This activity starts with motivation, introduction to entrepreneurship, market needs, product design, branding, and product marketing based on information technology. This activity's output gives the spirit of entrepreneurship, provides the family with additional income, and produces washing soap, traditional snacks, and convection businesses that are marketed offline and online.
\end{abstract}

Keywords: Poverty Alleviation; Empowerment; Gender; PKH; Indonesia

(c) 2020 Some rights reserved 


\section{PENDAHULUAN}

Persoalan kemiskinan menjadi salah satu hal utama yang dihadapi oleh negara Indonesia, dengan permasalahan yang beragam (Müller, 2015; Sawitri, 2020; Zulfa et al., 2020). Permasalahan kemiskinan khususnya di era pandemic Covid-19 merupakan persoalan multidimensi yang dihadapi bukan hanya di Indonesia, tetapi juga menjadi permasalahan bagi negara-negara berkembang dan terlebih lagi bagi negara miskin. Hal tersebut terjadi karena sektor ekonomi di suatu negeri tidak berjalan dengan baik disebabkan adanya keterbatasan pergerakan manusia yang ditimbulkan oleh Covid19 (Komala et al., 2020).

Badan Pusat Statistik (BPS) mendata jumlah persentase kemiskinan penduduk untuk bulan Maret Tahun 2020 hingga 9,78 persen, terjadi peningkatan kemiskinan 0,56 persen dibandingkan pada bulan September Tahun 2019, serta terjadi peningkatan 0,37 persen untuk bulan Maret Tahun 2019 (Ramadhani, 2020). Jumlah penduduk miskin di Sulawesi Selatan untuk bulan Maret Tahun 2019 berjumlah 767,80 jiwa, yang mengalami penurunan sebesar 24,83 ribu jiwa dibandingkan dengan kondisi bulan Maret Tahun 2018. Persentase penduduk miskin mengalami penurunan 9,06 persen kondisi bulan Maret Tahun 2018 menjadi 8,69 persen pada bulan Maret Tahun 2019. Persentase penduduk miskin mengalami penurunan untuk daerah perkotaan dan perdesaan selama periode bulan Maret 2018 sampai dengan bulan Maret 2019 (Selatan, 2019).

Usaha mengatasi persoalan sosial dengan memakai pendekatan entrepreneurship menjadi sebuah terobosan (Safarati et al., 2020), ditandai dengan bermacam bentuk kegiatan kewirausahaan sosial, seperti pembiayaan mikro Grameen Bank oleh Muhammad Yunus jasa keuangan Aavishkaar di Singapura, pembangunan jaringan listrik di Brazil yang dilakukan Fabio Rosa, pembangunan ekonomi masyarakat desa di Afrika oleh Paul Cohen, farm shop di Kenya oleh Ayer, serta bentuk wirausaha lainnya (Firdaus, 2014).

Berdasarkan pendekatan kewirausahaan tersebut, terutama di era pandemic Covid-19, bentuk kewirausahaan sangatlah dibutuhkan ditengah masyarakat (Wibowo et al., 2020). Socialpreneur merupakan bentuk usaha dengan memadukan spirit untuk tujuan sosial dengan ketekunan untuk berinovasi dan keuletan untuk menjalankan sebuah usaha (Vikaliana \& Andayani, 2018). Kewirausahaan merupakan keahlian yang kreatif dan inovatif, dengan teliti membaca kesempatan dan bersifat terbuka untuk masukan serta perubahan untuk hal positif sehingga bisa membuat usaha berkembang dan bernilai (Saragih, 2017).

Indonesia sebagai negara berkembang, socialpreneur tumbuh sangat baik sejalan dengan kepercayaan yaitu socialpreneur menjadi solusi untuk mengatasi permasalahan (Sukirman, 2017). Hal tersebut ditandai dengan berdirinya Asosiasi Kewirausahaan Sosial Indonesia (AKSI) di Tahun 2019 (Utomo, 2014). Penelitian terkait kewirausahaan seperti berdampak pada pemberdayaan dengan dilaksanakan pelatihan pembuatan jam tangan dari kayu, sehingga masyarakat memiliki keterampilan untuk membuka usaha sendiri, dengan bentuk pemasaran dilaksanakan dengan iklan di beberapa sosial media dengan pangsa pasar dalam dan luar negeri (Adinoto, 2013).

Penelitian yang lain terkait kewirausahaan dilakukan melalui industri rumahan dengan memproduksi ceriping pisang dengan berbagai rasa, industry rumahan tersebut dilakukan di Desa Banjarwaru Kecamatan Bawang Kabupaten Batang, kelebihan pelaksanaan kewirausahaan tersebut terlihat dari aneka macam rasa yang diproduksi, sebagai ciri khas dari industri rumahan yang dilaksanakan. Dengan menggunakan pisang yang berkualitas berdampak kepada kualitas hasil, sehingga memberikan dampak kepada masyarakat sekitarnya untuk menerap tenaga kerja (Nugroho, 2016).

Perbaikan sumber daya manusia melalui kewirausahaan terhadap masyarakat lokal di Desa Argosari untuk peningkatan kualitas wisata, berjalan dengan baik sesuai petunjuk dari pemerintah setempat sehingga berdampak pada perkembangan wisata di daerah tersebut, dengan bentuk penyuluhan untuk membentuk usaha padat karya berupa keripik kentang, sehingga masyarakat Desa Argosarii mampu memperbaiki taraf kehidupannya dan objek wisata juga telah berkembang dengan bagus (Ningsih, 2014).

Hasil observasi menunjukkan bahwa selama ini mitra belum pernah mendapatkan bentuk pelatihan berbasis entrepreneurship, bentuk pelatihan yang selama ini diberikan semacam pemahaman dalam menjalankan kewajiban rumah tangga, kewajiban untuk mendidik dan menyekolahkan anak. Terhadap ibu-ibu penerima bantuan PKH sebagai mitra pada Desa Padang Loang, dari beberapa bentuk pelaksanaan keterampilan dengan pembinaan yang pernah mereka terima, belum terdapat pengenalan dan pemahaman bahwa barang-barang kebutuhan rumah tangga seperti sabun cuci dan kebutuhan lainnya, seharusnya bisa untuk dilakukan pemrosesan produksi sendiri. 
permasalahan lain yang dihadapi mitra berkaitan dengan kehidupan perkotaan yang serba instan dan barang itu tersedia di toko-toko terdekat. Sehingga sangat dibutuhkan adanya pencerahan kepada ibu-ibu penerima bantuan PKH pada Desa Padang Loang tersebut bahwa beberapa barang kebutuhan rumah tangga kita dapat melakukan produksi sendiri, sehingga berdampak pada keringanan beban pengeluaran keluarga tiap hari. Karena dengan melakukan kegiatan produksi sendiri, biaya yang dikeluarkan juga pasti lebih murah dibandingkan dengan konsumsi barang produksi pabrikan yang kualitasnya hampir sama. formula serta bahan baku untuk pembuatan barang kebutuhan rumah tangga tersebut dijual bebas dan sangat mudah untuk didapatkan. Socialpreneur merupakan solusi yang baik untuk kegiatan pelatihan karena akan membentuk bentuk jiwa wirausaha yang dimiliki oleh ibu-ibu penerima bantuan PKH yang akan menciptakan kreatifitasnya dan inovatifnya, yang berdampak kepada terbentuknya sifat kemandirian. pengabdian ini memiliki maksud menggambarkan kewirausahaan untuk mengatasi persoalan kemiskinan dengan penerapan socialpreneur kepada ibu-ibu penerima bantuan Program Keluarga Harapan (PKH).

\section{METODE PELAKSANAAN}

Pengabdian yang dilaksanakan dengan bekerjasama Program Keluarga Harapan (PKH) Kabupaten Bone memilih masyarakat Desa Padang Loang Kecamatan Cina untuk melaksanakan socialpreneur bagi ibu-ibu penerima bantuan PKH berjumlah delapan orang. Kegiatan dilaksanakan pada bulan Mei sampai dengan bulan Agustus Tahun 2020. Metode mengatasi permasalahan kemiskinan dilakukan dengan pendampingan socialpreneur, dengan melalui beberapa tahap yaitu 1) motivasi kewirausahaan; 2) pengenalan socialpreneur; 3) pembuatan produk rumah tangga; 4) manajemen produksi; 5) branding produk; 6) pemasaran online.

Partisipasi Mitra dalam pelaksanaan, yaitu:

1. Mitra PKH membantu memberikan data ibu-ibu penerima bantuan untuk pelaksanaan kegiatan dan berkolaborasi melancarkan program kemitraan masyarakat.

2. Ibu-ibu penerima bantuan berpartisipasi dalam implementasi program kemitraan masyarakat.

3. Bekerjasama dalam memberikan sosialisasi kepada ibu-ibu penerima bantuan untuk serius dalam mensukseskan kegiatan ini, karena mereka sebagai unsur utama untuk pelaksanaan kegiatan agar nantinya dapat mandiri untuk berwirausaha.

\section{PEMBAHASAN \\ Persiapan}

Sebelum memulai kegiatan biasanya dilakukan persiapan tentang kegiatan yang akan dilaksanakan, hal ini sangat penting dan tidak boleh diabaikan (Wiratno, 2012). Tim pelaksana program kemitraan masyarakat melakukan perjanjian dengan mitra dalam hal ini pelaksana $\mathrm{PKH}$ Kecamatan Cina, mitra menyediakan daftar desa untuk ditentukan tempat yang akan dijadikan pelaksanaan socialpreneur.

Setelah penetapan desa telah disepakati bersama dengan mitra yaitu Desa Padang Loang Kecamatan Cina, tahap selanjutnya konsultasi kepada mitra untuk menentukan ibu-ibu penerima bantuan yang akan didampingi untuk pelaksanaan program pemberdayaan. Dari hasil tersebut, maka ditentukanlah delapan ibu-ibu penerima bantuan PKH untuk dibimbing dalam mensukseskan kegiatan ini.

\section{Pelatihan}

Menjadi socialpreneur memerlukan beberapa dasar pengetahuan, keterampilan, serta percaya diri ( Muljaningsih, at al, 2012). Melaksanakan PKM di Desa Padang Loang Kecamatan Cina selama tiga bulan. Untuk bulan pertama diberikan sosialisasi, motivasi dan pengenalan socialpreneur, dengan menjelaskan bagaimana jenis produk yang akan dijadikan untuk kegiatan wirausaha dalam hal ini fokus kepada kebutuhan rumah tangga. Bulan pertama ini menggambarkan antusias ibu-ibu penerima bantuan PKh untuk melaksanakan wirausaha, kemudian tahapan berikutnya diberikan keterampilan tentang pembuatan produk, dalam hal pembuatan sabun cuci piring, jajanan tradisional, dan usaha konveksi (Gambar 1).

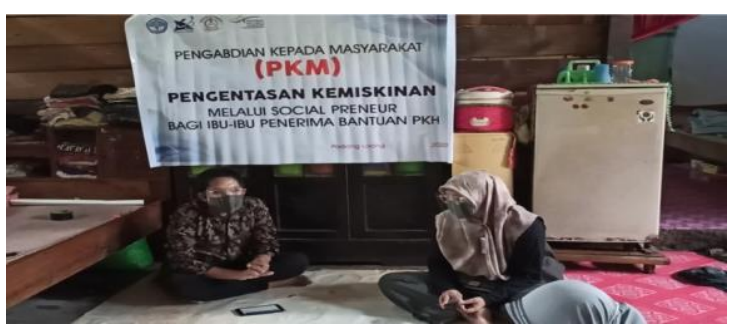

Gambar 1. Penyampaian materi socialpreneur

\section{Praktik}

Praktik ini dilakukan melalui landasan seimbang antara teori serta praktik untuk melaksanakan socialpreneur (Indriyatni et al., 2015). Kegiatan pembuatan sabun cuci piring, pembuatan jajanan tradisional, dan pembuatan sprei dan sarung bantal (Gambar 2), ibu-ibu binaan juga diberikan materi untuk penentuan harga jual jika nantinya 
produknya telah selesai, kemudian ibu-ibu binaan membuat buku keuangan untuk pembukuannya dengan menghitung modal yang digunakan untuk pembuatan sabun cuci, jajanan tradisional, dan usaha konveksi, persentase harga yang akan dijualkan, sehingga mereka dapat memahami bagaimana manajemen dalam berwirausaha. Sehingga setiap harinya ada catatan harian untuk menghitung laba yang bisa didapatkan.

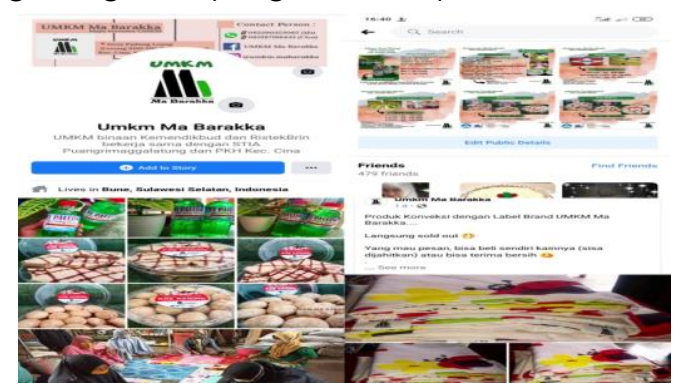

Gambar 2. Produksi kebutuhan rumah tangga

\section{Monitoring dan Evaluasi}

Dari 8 binaan ibu-ibu penerima bantuan PKH yang dibentuk dalam satu kelompok dengan menghasilkan tiga produk yang dikerjakan secara bersama dan telah ada pembagian job description kepada masing-masing ibu-ibu penerima bantuan PKH. Pelaksanaan evaluasi dengan mitra untuk kegiatan PKM, dengan cara melakukan sharing kepada ibu-ibu binaan terkait kegiatan socialpreneur yang telah dijalankan dengan membahas hambatan yang dialami, serta memperhatikan buku keuangan untuk memperhatikan kerugian atau keuntungan yang telah didapatkan dari hasil pemasaran produknya yaitu sabun cuci piring, jajanan tradisional, dan usaha konveksi (Gambar 3). Terlihat buku keuangan sudah mereka pahami, mulai dari modal yang dikeluarkan, keuntungan yang didapat dan catatan pengeluaran sehari-hari, semuanya sudah dicatat dalam buku keuangan secara baik, dari hasil tersebut selama proses kegiatannya hingga proses pemasaran menunjukkan keuntungan yang didapat oleh ibuibu penerima bantuan PKH dengan sebesar 40 persen.

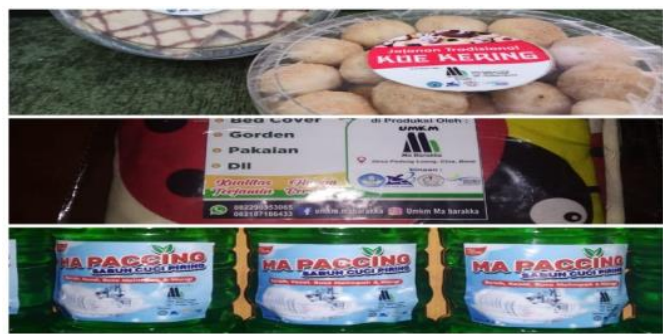

Gambar 3. Produk kebutuhan rumah tangga (sabun cuci, jajanan tradisional, sprei)
Kegiatan monitoring yang dilakukan, memperlihatkan pada saat pertama ibu-ibu binaan mendapatkan hambatan untuk berwirausaha, seperti cara pemasarannya lewat sosial media, karena mereka belum pernah bersosial media, selain itu untuk menyusun narasi terkait promosi produk secara online mereka juga belum terbiasa, juga hambatan mengambil gambar yang bagus dari produk untuk di upload mereka masih belum terbiasa. Kemudian dilakukan pendampingan lebih lanjut terkait strategi pemasaran di sosial media, terlihat ibu-ibu binaan sudah mendapatkan pengetahuan untuk membuat konten, memfoto dengan baik produk yang akan dipasarkan, mengenal social media dengan baik seperti facebook, instagram, dan tokopedia (Gambar 4).
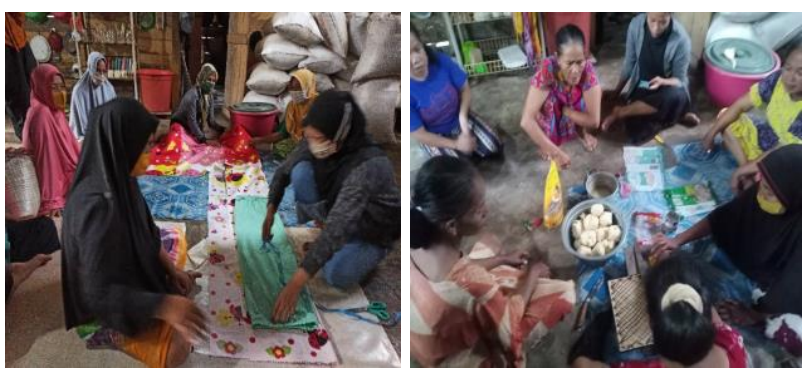

Gambar 4. Pemasaran di sosial media

Perbaikan sumber daya manusia melalui socialpreneur kepada ibu-ibu penerima bantuan PKH di Desa Padang Loang, dilaksanakan dengan baik, sesuai pedoman sehingga berdampak pada terbentuknya Usaha Kecil Mikro Menengah (UMKM), dengan pemberian teori dan praktek untuk membentuk usaha kebutuhan rumah tangga berupa sabun cuci piring, jajanan tradisional, dan kegiatan konveksi berdampak kepada masyarakat Desa Padang Loang yang mampu memperbaiki taraf kehidupannya dan kegiatan UMKM yang dilakukan telah mampu berkembang dengan bagus.

Keberhasilan ibu-ibu penerima bantuan PKH dengan mendirikan UMKM melalui pendekatan socialpreneur tidak terlepas dari semangat mitra. Ibu-ibu penerima bantuan PKH memiliki prinsip disiplin. Prinsip tersebut merupakan ciri khas dari socialpreneur (Mahfud, 2012). Ditandai dengan dibentuknya UMKM "Ma'Barakka", socialpreneur pada dasarnya adalah usaha yang diperoleh didistribusikan kembali untuk tujuan sosial dan sustainability (Dueck et al., 2010). Kegiatan socialpreneur oleh ibu-ibu penerima bantuan PKH menjadi suatu strategi dalam pengentasan kemiskinan. Nilai socialpreneur menjadi pendorong bagi ibu-ibu penerima bantuan PKH untuk mandiri, Ini yang membedakan antara pengentasan 
kemiskinan dengan socialpreneur yang selama ini tidak difokuskan kepada penerima bantuan PKH.

\section{KESIMPULAN}

Kegiatan PKM yang dilaksanakan di Desa Padang Loang Kecamatan Cina, dengan tujuan pengentasan kemiskinan melalui penerapan socialpreneur kepada masyarakat khususnya ibuibu penerima bantuan PKH tercapai dengan baik,. Hal tersebut terbukti dengan meningkatnya pendapatan ibu-ibu penerima bantuan PKH. Manajemen keuangan, dan modal produk diserap dengan baik ibu-ibu binaan, mitra sudah mengetahui langkah-langkah pengembangan kewirausahaan. Strategi pemasaran melalui social media, untuk pemasaran produknya dilakukan secara luring dan daring. Program pengabdian dapat dilanjutkan dengan peningkatan kegiatan kolaborasi dengan institusi terkait seperti pemerintah daerah dan pelaku usaha UMKM, dinas sosial, pendamping $\mathrm{PKH}$ untuk memunculkan inovasi kreatif dalam hal pengembangan pengentasan kemiskinan.

\section{UCAPAN TERIMA KASIH}

Ucapan terima kasih kepada Kementerian Pendidikan dan Kebudayaan (Kemendikbud), Kementerian Riset, Teknologi/ Badan Riset dan Inovasi Nasional (Ristek/BRIN), Sekolah Tinggi IImu Administrasi Puangrimaggalatung, Program Keluarga Harapan, Pemerintah Daerah Kabupaten Bone, dan Pemerintah Kecamatan Cina.

\section{DAFTAR PUSTAKA}

Adinoto, A. (2010). Pengaruh Orientasi Pasar dan Perilaku Kewirausahaan Terhadap Kepekaan Perusahaan Dan Implikasinya Pada Kinerja Perusahaan: Studi pada Penyalur Sepeda Motor di Indonesia. Ultima Management: Jurnal IImu Manajemen, 2(1), 1-25. http://ejournals.umn.ac.id/index.php/manajemen/a rticle/view/166

Dueck, C., Menteri Kelautan dan Perikanan Republik Indonesia, KKP, Spell, C. S., Ayuningtas, H. Y., Studi, R., Akuntansi, K., Kessler, R., Sekolah, D., Agama, T., Negeri, I., Nurmianto, E., Siswanto, N., Sapuwan, S., Christiawan, Y. J., Matias, L., Fallis, A. ., Pada, U., Ekonomi, S., ... Dan, P. (2010). Pengembangan-SdmBerbasis-Kompetensi.Pdf. Jurnal Manajemen Dan Kewirausahaan. https://doi.org/10.1017/CBO9781107415324.004

Firdaus, N. (2014). Pengentasan Kemiskinan melalui Pendekatan Kewirausahaan Sosial. Jurnal Ekonomi Dan Pembangunan, 22(1), 55-67. http://www.jurnalekonomi.lipi.go.id/JEP/article/view/ 29

Indriyatni, L., Purwanto, A. B., \& Wahyuningsih, P. (2015). Pengembangan Model Pelatihan Kewirausahaan untuk Perempuan Pengangguran di Kabupaten Demak. Jurnal Aplikasi Manajemen, 13(2), 313-325. https://jurnaljam.ub.ac.id/index.php/jam/article/vie $w / 772$

Komala, L., Budiyanto, A., Wibowo, W. A., Praditya, A., \& Pamungkas, I. B. (2020). Membangun Kreativitas dan Kemandirian Masyarakat di Masa Pandemi CVID-19. DEDIKASI PKM, l(2), 20-24. http://openjournal.unpam.ac.id/index.php/DKP/arti cle/view/6384

Mahfud, T. (2012). Praksis pembelajaran kewirausahaan pada unit produksi jasa boga. Jurnal Pendidikan Vokasi, 2(1), 27-40. https://doi.org/10.21831/jpv.v2i1.1014

Müller, F. (2015). Sustainable Development Goals (SDGs). PERIPHERIE - Politik • Ökonomie • Kultur. https://doi.org/10.3224/peripherie.v35i140.23001

Ningsih, S. (2014). Realistic Mathematics Education: Model Alternatif Pembelajaran Matematika Sekolah. Jurnal Pendidikan Matematika, l(2), 73-94. https://doi.org/https://doi.org/10.18592/jpm.v1i2.97

Nugroho, A. (2016). Strategi Pengembangan Kewirausahaan Masyarakat Melalui Home Industri Ceriping Pisang Desa Banjarwaru Kecamatan Bawang Kabupaten Batang. Skripsi. Universitas Negeri Semarang. https://lib.unnes.ac.id/24073/

Ramadhani, P. I. (2020). Penduduk Miskin Indonesia Naik Jadi 26,42 Juta Orang di Maret 2020 https://www.liputan6.com/bisnis/read/4305950/pen duduk-miskin-indonesia-naik-jadi-2642-juta-orang-dimaret-2020

Safarati, N., Studi Pendidikan Fisika, P., \& Keguruan dan IImu Pendidikan, F. (2020). Pelatihan Inovasi Pembelajaran Menghadapi Masa Pandemic COVID-19. Communnity Development Journal, 1(3), 240-245. http://bit.ly/WebinarPendFisika.

Saragih, R. (2017). Membangun usaha kreatif, inovatif dan bermanfaat melalui penerapan kewirausahaan sosial. Jurnal Kewirausahaan, 3(2), 26-34. http://ejournal.Imiimedan.net/index.php/jk/article/vi ew/21

Sawitri, D. (2020). Penggunaan Google Meet Untuk Work From Home Di Era Pandemi Coronavirus Disease 2019 (Covid-19). Prioritas: Jurnal Pengabdian Kepada Masyarakat, 2(01), 13-21. http://jurnal.harapan.ac.id/index.php/Prioritas/articl e/view/161

Selatan, B. S. (2019). Profil Kemiskinan Sulawesi Selatan, Maret 2019. Badan Pusat Statistik Sulawesi Selatan.

Sukirman, S. (2017). Jiwa Kewirausahaan dan Nilai Kewirausahaan Meningkatkan Kemandirian Usaha melalui Perilaku Kewirausahaan. Jurnal Ekonomi Dan Bisnis, 20(1),

113-131. https://doi.org/10.24914/jeb.v20i1.318

Utomo, H. (2015). Menumbuhkan minat kewirausahaan sosial. Among Makarti, 7(14).1-16. https://jurnal.stieama.ac.id/index.php/ama/article/v iew/99

Vikaliana, R., \& Andayani, A. (2018). Social Entrepreneurship: Kewirausahaan Perempuan di Bogor melalui Pengolahan Kain Perca Limbah Konveksi menjadi Aksesoris. JPM (Jurnal Pemberdayaan Masyarakat), 3(2), 323-329. https://doi.org/https://doi.org/10.21067/jpm.v3i2.286 4

Wibowo, A., Pradiptha, A. P., Mulyati, M., \& Utari, D. R. (2020). Penyuluhan Wirausaha Berbasis Teknologi untuk Pemulihan Ekonomi Masyarakat Terdampak 
Covid-19 di Masa New Normal. E-Dimas: Jurnal Pengabdian Kepada Masyarakat, 11 (3), 357-365. https://doi.org/10.26877/e-dimas.v1 1 i3.5872

Wiratno, S. (2012). Pelaksanaan pendidikan kewirausahaan di pendidikan tinggi. Jurnal Pendidikan dan Kebudayaan, 18(4), 454-466. http://jurnaldikbud.kemdikbud.go.id/index.php/jpnk /article/view/101

Muljaningsih, S., Soemarno, S., Hadiwidjojo, D., \& Mustadjab, M. M. (2012). Faktor-Faktor Yang Mempengharuhi Minat Wirausaha Pengolahan Pangan Organik Pada Perempuan Tani Di Desa Wonokerto, Bantur, Malang. WACANA, Jurnal Sosial dan Humaniora, 15(2), 12-18. https://wacana.ub.ac.id/index.php/wacana/article $/$ view/265

Zulfa, L. L., Mujibah, M., \& Rajaguguk, Z. F. (2020). Pelatihan Penggunaan Perangkat Berbasis Internet dalam Pengumpulan Data Penelitian Masa Pandemi COVID-19. Kilas Artikel Abstrak, 1(2), 143-158. https://doi.org/10.30997/ejpm.v1i2.2835 